DOI: $10.2478 /$ lpts-2018-0003

\title{
CONSISTENCY ANALYSIS AND DATA CONSULTATION OF GAS SYSTEM OF GAS-ELECTRICITY NETWORK OF LATVIA
}

\author{
L. Zemite ${ }^{1}$, A. Kutjuns ${ }^{1}$, I. Bode ${ }^{1}$, M. Kunickis ${ }^{2}$, N. Zeltins ${ }^{3}$ \\ ${ }^{1}$ Riga Technical University, \\ Faculty of Power and Electrical Engineering, Institute of \\ Industrial Electronics and Electrical Engineering, \\ 12-1 Azenes Str., Riga, LV-1048, LATVIA \\ ${ }^{2}$ JSC Latvenergo, \\ Pulkveza Brieza Str. 12, Riga, LV-1230, LATVIA \\ ${ }^{3}$ Institute of Physical Energetics \\ 11 Krivu Str., Riga, LV-1006, LATVIA
}

In the present research, the main critical points of gas transmission and storage system of Latvia have been determined to ensure secure and reliable gas supply among the Baltic States to fulfil the core objectives of the EU energy policies.

Technical data of critical points of the gas transmission and storage system of Latvia have been collected and analysed with the SWOT method and solutions have been provided to increase the reliability of the regional natural gas system.

Keywords: Baltic countries, capacity of pipelines, critical points, reliability, gas storage system, security, gas transmision system

\section{INTRODUCTION}

To achieve long-term state and energy strategic goals, one of the basic conditions is diversification of energy sources and security of energy supplies. For a long time, the core objectives of the EU energy policies are competitiveness, sustainability and security of supply. In February 2015, the EU Commission launched work on the European Energy Union. Security of supply is defined as one of five European Energy Union's strategy vectors. Natural gas takes an essential part in the EU energy balance as it makes approximately $25 \%$ of primary energy source consumption, and it is used mainly for electricity [1].

Natural gas is an important resource for the Latvian economy and energy system, and it plays an important role in the energy conversion sector - production of heat and electricity. The largest consumer of natural gas in Latvia is JSC Latvenergo, which uses natural gas mainly for combined heat and power production. Thus, dis- 
ruptions in natural gas supply system would impact both the industrial and household sectors. Natural gas supply is one of the national security issues. That is why security of natural gas supply and the necessity of more precise assessment of risks of possible disruptions become increasingly acute. In the assessment of natural gas supply system security, security standards of the EU natural gas supply system are used in Latvia. Still these standards do not cover, to a full extent, the specifics of the Latvian situation [2], [3].

\section{THE LATVIAN GAS - POWER SUPPLY SYSTEM AND ITS DEVELOPMENT PROSPECTS}

JSC “Conexus Baltic Grid” (founded in 2017) ensures operation for Incukalns underground gas storage, a gas transmission pipeline system with an overall length of $1191 \mathrm{~km}$, a gas distribution pipeline system with an overall length of $4950 \mathrm{~km}$, comprising a network of natural gas pipelines, gas regulation devices, and electrical protection devices. Latvia's natural gas transmission infrastructure is part of the natural gas transmission system of the Baltic States. The existing intercountry natural gas transmission system makes it possible to receive natural gas via intercountry gas transmission pipelines. Supply of natural gas in the direction from Pskov to Riga is ensured via two parallel gas pipelines, between which there are connecting lines $[4],[5]$.

Since 2000, medium-pressure $(\mathrm{P}<0.01 \mathrm{MPa} ; \mathrm{P}<0.4 \mathrm{MPa})$ distribution pipeline systems have been built in individual dwelling areas and high-pressure $(\mathrm{P}<1.6 \mathrm{MPa})$ distribution pipeline systems in industrial territories, which can ensure the operation of potential micro cogeneration and cogeneration units from the existing distribution pipeline system. 65 million EUR have been invested into the construction of new gas distribution pipelines, building $4950 \mathrm{~km}$ of distribution pipelines, providing connections for 40.85 thousand clients, which makes up approx. $50 \%$ of all the possible connections to the newly built distribution system. Figure 1 shows the existing gas system [4]-[7].

Over the past 15 years, the most considerable number of applications and, consequently, connections have been observed in the territories of Riga region Marupe, Kekava, Carnikava, Stopini, Adazi, Olaine, Jurmala -, where the largest investments have been made into the development of the distribution network. In 2014, new connections were built for 1211 clients; capacity was increased for 435 clients, thus connecting or increasing capacity for 1646 clients in total. In 2014, 31.3 $\mathrm{km}$ of new distribution system pipelines were built, with total investments of 1.2 million EUR [6]-[9].

The structure of the new connections made in 2016 is as follows: individual houses $-69 \%$, industrial clients $-12 \%$, commercial clients $-9 \%$, and flats $-10 \%$. The transmission system ensures complete natural gas supply for the country's major cities, considering the existence of the connecting joint between the transmission joint, namely, the transmission capacity reserves of the gas-regulating stations. Natural gas sales in 2016 compared to 2015 decreased by $9.45 \%$ (in absolute terms 120 $000000 \mathrm{~m}^{3}$ ) [6], [7]. 


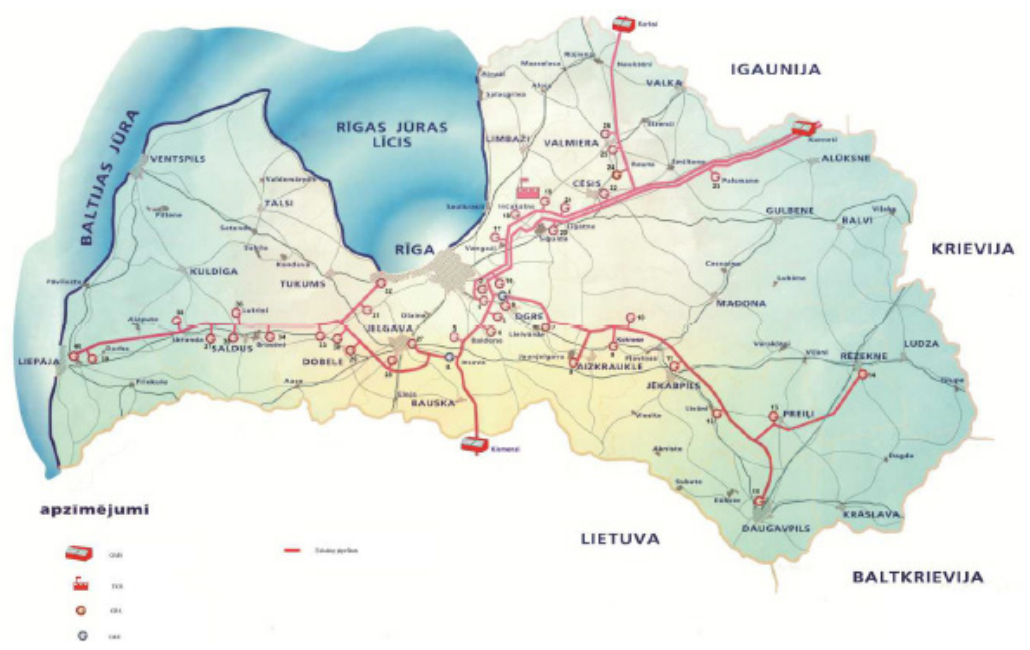

Fig. 1. The existing gas system.

As regards the development of the natural gas infrastructure, it is necessary to take account of the limited natural gas market of the Baltic States and, hence, the repayment potential of the project if there is no investment support. In order to ensure energy independence regarding natural gas deliveries, a number of important interconnection infrastructures in the Baltic region were identified within BEMIP for the PCI list, for example:

- Gas Interconnector Poland-Lithuania (GIPL);

- Improvement of the Latvia-Lithuania gas interconnection;

- The regional LNG terminal;

- Enlargement and modernization of Incukalns UGS;

- Improvement of the Latvia-Estonia gas interconnection [3], [8].

Figure 2 shows the distribution of the natural gas supplied from Incukalns UGS among the consumers of the three Baltic States and Russia in the time period from 2000 till 2014. In this period, the bulk of the natural gas from Incukalns UGS was supplied to Latvia, Lithuania, Estonia, and Russia. Incukalns UGS has the potential of being enlarged in the future, thus storing a larger amount of gas. The amount of stored active gas can be increased from 2.32 billion $\mathrm{m}^{3}$ to 2.6 ...2.8 billion $\mathrm{m}^{3}$. After enlargement, also the amount of natural gas supplied to and from the storage is to increase from $28 . .30$ billion $\mathrm{m}^{3} /$ day to $34 . . .35$ billion $\mathrm{m}^{3} /$ day.

Apart from Incukalns UGS, in Latvia there are also other sites that can potentially be used for storing natural gas. These may acquire additional significance after interconnections with the EU networks have been built. The issues of UGS availability and sufficiency in the region are important, since UGS considerably improve the reliability of natural gas supply and make it possible to regulate the supply of gas depending on the season. Of Latvia's potential UGS, Dobele underground structure has been investigated in the greatest detail and has been acknowledged a suitable site for natural gas storage. Within a project co-financed by the EU, it was acknowledged that, if a UGS were built in Dobele structure, it would rank among the EU's largest UGS in terms of capacity [3], [5], [10]. 


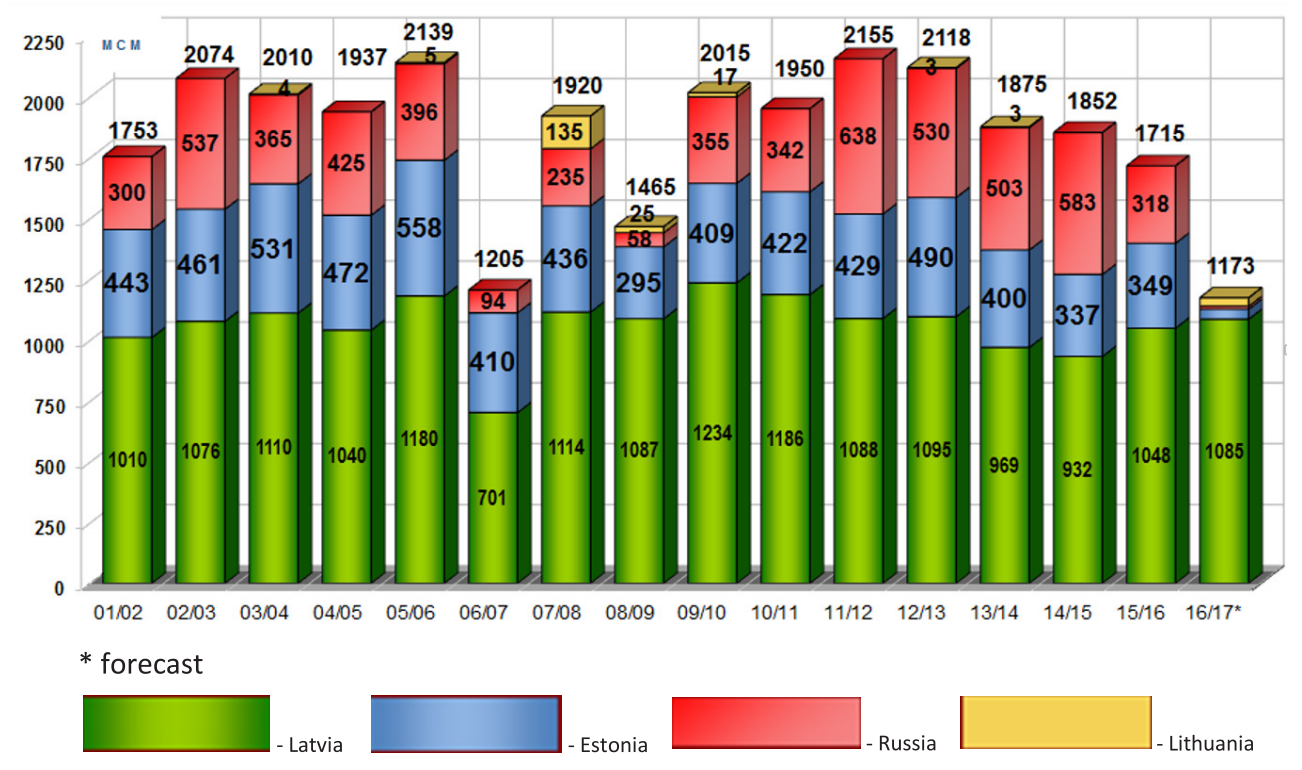

Fig. 2. Natural gas supply from Incukalns UGS in 2000-2014, millions $\mathrm{m}^{3}$.

In 2014, the share of natural gas in the total consumption of primary energy resources was $24.4 \%$. In Latvia, natural gas is mainly used for producing electricity and heat. In order to encourage the diversification of natural gas supply paths and sources as well as the emergence of a natural gas market, BEMIP states a list of the required infrastructure entities, which foresees the construction of the Gas Interconnector Poland-Lithuania as well as the improvement of the Latvia-Lithuania and Latvia-Estonia interconnections and the modernization and enlargement of Incukalns underground gas storage, which will increase the natural gas supply reliability and stability in the region [3], [11]-[14].

Uninterrupted operation of the natural gas infrastructure has to be ensured at all levels, yet primarily on a regional scale. The situation when critical disturbance arises in one major element of the gas supply infrastructure is characterised by the infrastructure safety indicator (criterion) $\mathrm{N}-1$. If this criterion in the region is equal to at least $100 \%$, then in the case of some disturbance in this element, the natural gas deliveries can be organised in such a way as to avoid any natural gas supply limitations. In the Baltic States, the $\mathrm{N}-1$ criterion is $145.94 \%$, provided that gas is available at Incukalns UGS. In case of calculating the $\mathrm{N}-1$ criterion, only the capacities of the natural gas supply system entrance points are taken into account. Figure 3 shows natural gas supply to the Baltic States in summer and Fig. 4 - in winter [15]-[17].

Power transmission system in Latvia operated by JSC Augstsprieguma tikls consists of $330 \mathrm{kV}$ and $110 \mathrm{kV}$ transmission lines and substations located throughout the entire territory of Latvia, ensuring operation, maintenance and repairs of substations and devices set by distribution points, as well as is engaged in further development of the company. Latvian transmission network receives electricity from hydroelectric and thermal power stations of Latvia, as well as Lithuania and Estonia and transfers it further to the companies of distribution networks [2], [15], [18], [19]. 


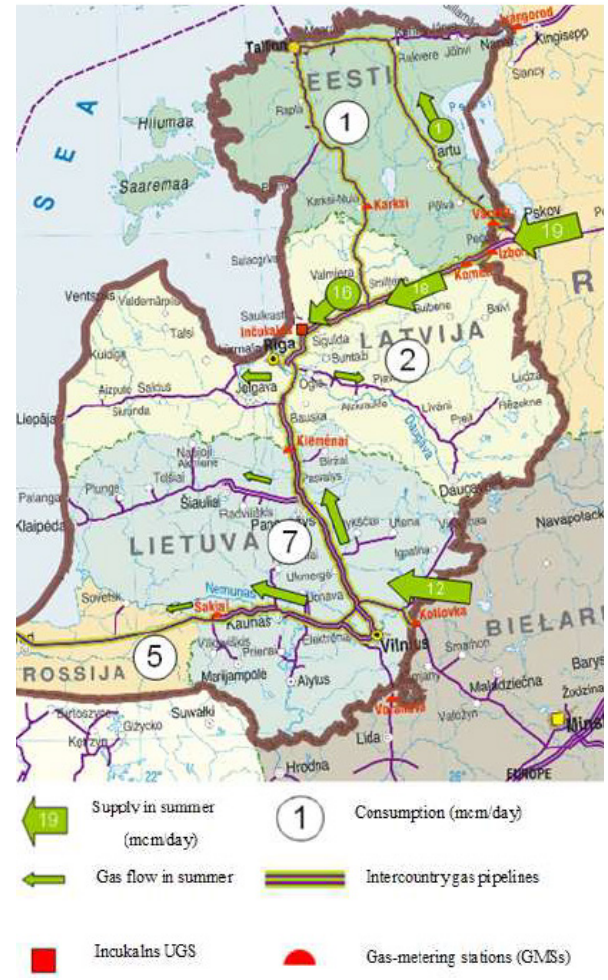

Fig. 3. Gas supply to the Baltic States in summer.

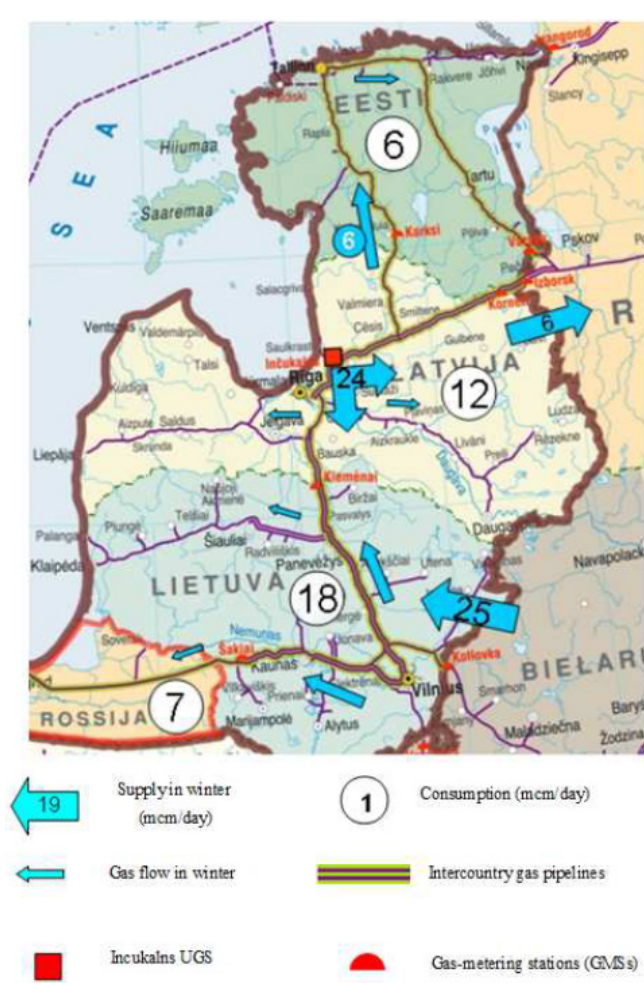

Fig. 4. Gas supply to the Baltic States in winter.

19 electricity clients are directly connected to the transmission network in Latvia, including 5 thermal power plants (4 CHP-s and 1 Biomass) with total installed capacity of approx. $1050 \mathrm{MW}, 3$ hydro power plants located on the Daugava River with total installed capacity of approx. $1550 \mathrm{MW}, 1$ wind farm, 4 major customers and 6 distribution network operators [11], [20], [21].

Transmission network in Latvia consists of 6 connections with neighbouring countries: 2 synchronized AC (alternative current) connections with Estonia, 4 AC connections with Lithuania and $1 \mathrm{AC}$ connection with Russia. The $330 \mathrm{kV}$ transmission network is a very significant network not only at the Latvian level but also at the international level. $330 \mathrm{kV}$ transmission network connects the Latvian power system with neighbouring power systems of Estonia, Lithuania and Russia, receives the produced electrical energy from the biggest hydro plants (Plavinas HPP and Riga HPP) and from 2 combined heat power plants (Riga CHP1 and Riga CHP2) in Latvia, as well as from energy producers in Estonia, Lithuania, Russia and Nordic countries and delivers it to lower voltage networks. $330 \mathrm{kV}$ transmission network provides a reliable corridor for transit of electrical energy through the Latvian transmission network from the Baltic and Nordic countries. Through $330 \mathrm{kV}$ autotransformers, electrical energy is delivered to the $110 \mathrm{kV}$ transmission network. The $330 \mathrm{kV}$ transmission network in Latvia is a middle node of the Baltic power systems between North and South parts. All $330 \mathrm{kV}$ substations are supplied from at least two sides, the exemption is $330 \mathrm{kV}$ substation in Daugavpils, which is connected to $330 \mathrm{kV}$ 
transmission network from one side, but with two $330 \mathrm{kV}$ transmission lines which could be considered the highest reliability in comparison with 1 line. Due to security of supply reasons, all $330 \mathrm{kV}$ substations are with 2 autotransformers, and in emergency or repair modes of one autotransformer the second will provide all substation power to lower voltage [11], [15], [21].

$110 \mathrm{kV}$ transmission network in Latvia is a local network, which provides electrical energy supply for the state regions, big cities, distribution networks and directly to the energy consumers connected to the transmission network. The $110 \mathrm{kV}$ transmission network is constructed as a ring scheme network and almost all $110 \mathrm{kV}$ substations are connected to the transmission network at least from 2 sides, which significantly improve power supply reliability. Due to security of supply reasons, in the main part of $110 \mathrm{kV}$ substations the two transformers are installed, because in emergency or repair modes of one transformer the second will provide all substation power to lower voltage. The Latvian transmission network scheme is shown in Fig. 5 [12]-[15].

The largest electrical energy producers in Riga are two CHP or cogeneration plants Riga CHP-1 and Riga CHP-2, as well as Riga HPP of JSC Latvenergo. Additional electrical energy is provided by independent cogeneration power plant Imanta CHP, operated by JSC Rigas Siltums, and by other small cogeneration power plants, whose impact on the whole power adequacy of Riga city is insignificant. All the above-mentioned power plants are connected to the transmission power network. The largest electrical energy producers (Name of power plant - Installed capacity in MW - Fuel) are as follows: Riga CHP-1, 144, natural gas; Riga CHP-2, 880, natural gas; Riga HPP, 402, water; Imanta CHP, 48, natural gas [12], [15], [19], [21].

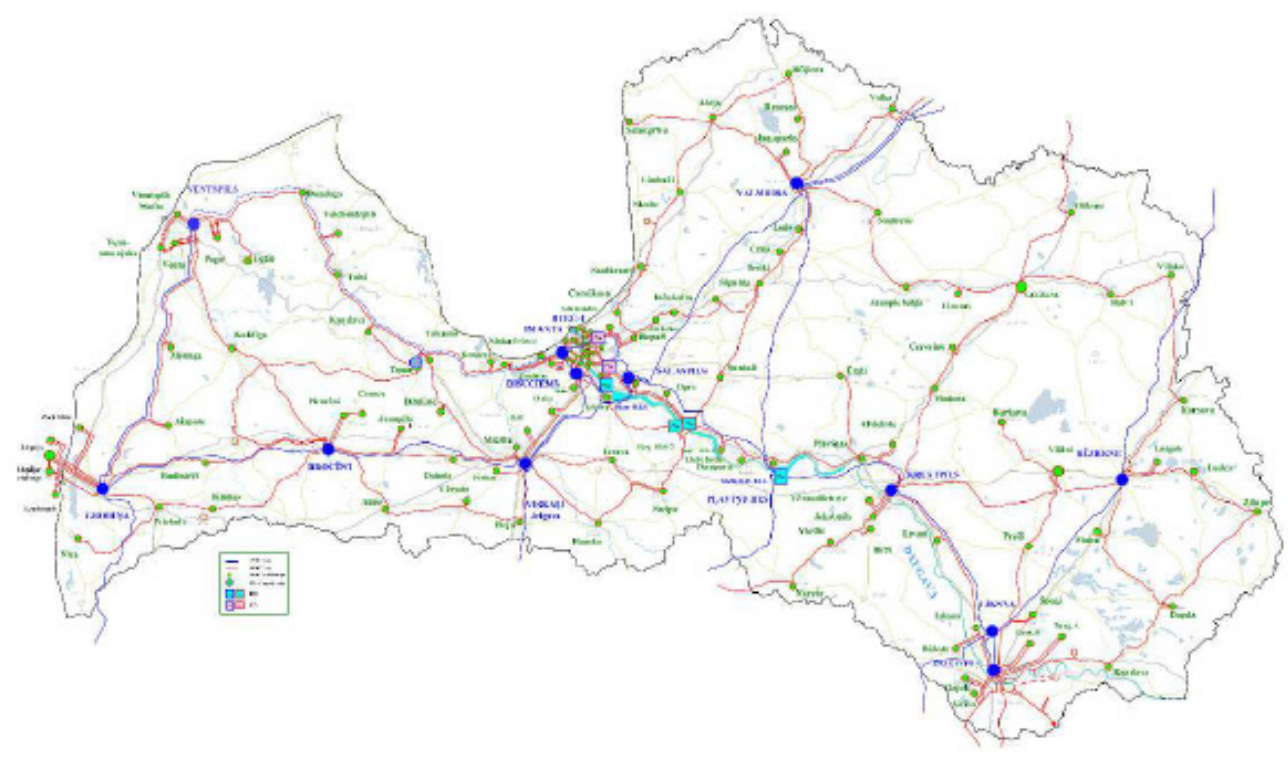

Fig. 5. $330 \mathrm{kV}$ and $110 \mathrm{kV}$ power transmission network scheme in Latvia. 


\section{CRITICAL INFRASTRUCTURE}

Upon examining the natural gas supply system of Latvia, it can be seen that seven critical points can be determined, which may influence natural gas supply reliability [3], [13], [16], [17], [22]-[24].

1. KIEMENAI gas metering station. The station is situated in the territory of the Republic of Lithuania. The transmission system operators of both countries, JSC Conexus Baltic Grid and JSC Amber Grid (Lithuania) have signed a contract regarding the use of the measurements made at the gas-metering station in the metering of gas transported across borders and the measurement of its quality. The requirements regarding the quality of natural gas are laid down in Latvian State Standard LVS 459 "Natural Gas. Properties, Parameters, Quality Assessment of Gas" (Latvian State Standard LVS459). The capacity of the station is 6.48 million $\mathrm{m} \mathrm{m}^{3} /$ day. The gas-metering station ensures the transport of natural gas from Lithuania to Latvia and Estonia, as well as from Estonia, and Latvia to Lithuania. Power supply of gas metering station is provided from substation "Bauska" through two $110 \mathrm{kV}$ transmission lines and respectively trough the 20 $\mathrm{kV}$ network. Reservation of power supply can be implemented through $20 \mathrm{kV}$ network, and additional autonomous diesel generators are installed in the gas metering station.

2. KARKSI gas metering station. The station is situated in the territory of the Republic of Estonia. The transmission system operators of both countries, JSC Conexus Baltic Grid and JSC Elering (Estonia) have signed a contract regarding the use of the measurements made at the gas-metering station in the metering of gas transported across borders and the measurement of its quality (Latvian State Standard LVS459). The capacity of the station is 6.96 million billion $\mathrm{m}^{3} /$ day. The station ensures the transport of natural gas from Latvia to Estonia and from Estonia to Latvia. Power supply of gas metering station is provided in Estonia. Reservation of power supply can be implemented from Latvia through $20 \mathrm{kV}$ network, and additional autonomous diesel generators are installed in the gas metering station.

3. KORNETI gas metering station. The station is situated in the territory of the Republic of Latvia. The station meters the gas and measures its quality. The transmission system operators of both countries, JSC Conexus Baltic Grid and JSC Gazprom (Russia) have signed a contract regarding the use of the measurements made at the gas-metering station in the metering of gas transported across borders and the measurement of its quality. The requirements regarding the quality of natural gas are laid down in Latvian State Standard LVS 459. The capacity of the station is 20 million billion $\mathrm{m}^{3}$ /day. This capacity makes it possible to transport natural gas via the transmission system of JSC Conexus Baltic Grid to Incukalns underground gas storage as well as to Lithuania and Estonia. Power supply of gas metering station is provided through $20 \mathrm{kV}$ network. Reservation of power supply can be implemented through $20 \mathrm{kV}$ network, and additional autonomous diesel generators are installed in the gas metering station.

4. Incukalns underground gas storage. Incukalns UGS ensures pumping-in of gas in the summer period and pumping-out of gas in the winter period. The amount of gas that can be stored is 4.5 billion $\mathrm{m}^{3}$ (active gas 2.3 billion $\mathrm{m}^{3}$ ). The pumping-in 
capacity in the summer season is 17 million $\mathrm{m} 3$ /day and the maximum pumpingout capacity is 28 million billion $\mathrm{m}^{3} /$ day. Incukalns underground gas storage is the only gas storage in the Baltic region. Incukalns UGS ensures the storage of a safety reserve of natural gas for the whole region. This UGS is equipped with a metering unit, which ensures the metering and quality monitoring of the gas pumped in and out in compliance with Latvian State Standard LVS 459. Power supply of IUGS is provided from substation "Incukalns" through two $110 \mathrm{kV}$ transmission lines and, respectively, thought the $20 \mathrm{kV}$ network. Reservation of power supply can be implemented through $20 \mathrm{kV}$ network, and additional autonomous diesel generators are installed in the IUGS.

5. RIGA 1 gas regulation station. Gas-regulating station Riga 1 ensures the supply of natural gas to Riga CHP-1 of JSC "Latvenergo". The capacity of the station is 175 thousand billion $\mathrm{m}^{3} / \mathrm{h}$. Gas-regulating station Riga 1 ensures gas metering and quality measurements in compliance with Latvian State Standard LVS 459. The location of metering stations at these facilities will ensure gas quality assessment for the following consumers: the obtained data will be used for billing the consumers of the right bank of the Daugava in Riga; the data will also be sent to GRS Riga 3, which supplies gas to Riga CHP-2. Power supply of GRS Riga 1 is provided from $330 \mathrm{kV}$ substation "Riga CHP-1" network through $110 \mathrm{kV}$ trans-mission lines and respectively the $20 \mathrm{kV}$ network. Reservation of power supply can be realised through $20 \mathrm{kV}$ network and additional autonomous diesel generators are installed in the GRS. Primary equipment of CHP-1 was commissioned in 2005, excluding heat only boiler (HOB) No. 3 which started its operation in 2010. Generating equipment of CHP-1 consists of combined cycle gas turbine (CCGT) double unit with installed heat capacity of $145 \mathrm{MWth}$ and electric capacity of $144 \mathrm{MWel}$ as well as three heats only boilers with heat capacity of 348 MWth. Thus, total installed heat capacity of CHP-1 is 493 MWth and electric capacity is $145 \mathrm{MW}$ th. The main fuel for CCGT unit and HOBs is natural gas while light oil (diesel) is used as the emergency fuel for heat only and auxiliary boilers.

6. RIGA 3 gas regulation station. Gas-regulating station Riga 3 ensures the supply of natural gas to Riga CHP-2 of JSC Latvenergo. The capacity of the station is 300 thousand billion $\mathrm{m}^{3} / \mathrm{h}$. Gas-regulating station Riga 3 ensures gas metering and quality measurements in compliance with Latvian State Standard LVS 459. Power supply of GRS Riga 3 is provided from $330 \mathrm{kV}$ substation "Riga CHP-2" network through $110 \mathrm{kV}$ transmission lines and, respectively, the 20 $\mathrm{kV}$ network. Reservation of power supply can be implemented through $20 \mathrm{kV}$ network, and additional autonomous diesel generators are installed in the GRS.

Primary equipment of CHP-2 was commissioned during the period from 1973 to 2013. CCGT unit No.1 and its auxiliary systems started its operation in 2008, while CCGT unit No.2 and its auxiliary systems were launched in 2013. CHP-2 heat only boilers HOB-1, 2, 3 and 4, originally built from 1973 to 1993, were reconstructed during 2009-2011. Installation of low NOx burners allowed reducing NOx emissions. Heat only boiler No. 5 was put in operation in 2013. Installed electric capacity of CCGT unit No. 1 is $413 \mathrm{MWel}$ in cogeneration mode and $442 \mathrm{MWel}$ in condensing mode, while installed heat capacity is $274 \mathrm{MW}$ th. 
Output of CCGT unit No. 2 is slightly different: installed electric capacity in cogeneration mode is $419 \mathrm{MWel}$, in condensing mode $439 \mathrm{MWel}$, heat capacity is $270 \mathrm{MWth}$. Total heat capacity of five heat only boilers HOB-1, 2, 3, 4, 5 is 580 MWth. Considering the whole plant, CHP-2 installed capacity in cogeneration mode is $832 \mathrm{MWel}$, in condensing mode $881 \mathrm{MWel}$ and overall heat capacity is 1124 MWth. Similarly to CHP 1, natural gas is used as the main fuel and diesel is used as the emergency fuel for CHP-2.

7. ZIEMELI gas regulation station. The station ensures the supply of natural gas to the city of Riga and to the western part of the Republic of Latvia, including national-status cities: Jelgava, Jurmala, and Liepaja. The capacity of the station is 150 thousand billion $\mathrm{m}^{3} / \mathrm{h}$. The gas-regulating station ensures gas metering and quality measurements in compliance with Latvian State Standard LVS 459. The location of metering stations at these facilities will ensure gas quality assessment for consumers in the following locations: Riga left bank, Balozi, Kekava, Iecava, Code, Bauska, and Uzvara. The data obtained at GRS Ziemeli will also be used at the gas-regulating stations of the villages of Baldone and Daugmale. Power supply of gas metering station is provided from substation "Iecava" through two $110 \mathrm{kV}$ transmission lines and, respectively, through the $20 \mathrm{kV}$ network. Reservation of power supply can be implemented through $20 \mathrm{kV}$ network, and additional autonomous diesel generators are installed in the gas metering station [6], [7], [11], [14], [22].

\section{INCREASING THE RELIABILITY OF THE REGIONAL NATURAL GAS SYSTEM}

The existing scheme of gas supply is in proper order and duly ensures the required capacities. To increase the reliability of the regional gas supply system, the following should or can be done:

- The capacities of the intercountry connections have to be increased: reconstruction of the border-area GMS Karksi and Kiemenai to increase the flow rate; construction of a reverse unit at GMS Karksi;

- A new transmission pipeline can be built to replace the Riga-Vilnius pipeline that has been allocated for the needs of the distribution system;

- A connection between the pipelines Riga-Daugavpils and Vilnius-Visaginas can be made (40 km, DN 400);

- A connection between the pipelines Iecava-Liepaja and PanevezysKlaipeda can be made (95 km, DN 400);

- The overall capacity and the gas pumping-out capacity of Incukalns UGS has to be increased;

- Additional compressors at Incukalns UGS can increase the amounts pumped in and ensure compressed pumping-out;

- In order to plan and be able to switch over gas flows, a regional SCADA system is needed with dynamic software of hydraulic calculations linked to it [3], [5], [6], [18], [21], [23], [24]. 


\section{SWOT ANALYSIS}

Strengths:

- A high natural gas reliability level with a natural gas infrastructure reserve of $45 \%$;

- A technologically optimal high-pressure natural gas transmission infrastructure in Latvia, especially in territories with a higher level of economic activity;

- A good technical condition of the natural gas transmission and distribution pipelines, modernized and reconstructed gas-metering stations;

- Natural gas supply in the winter period is ensured by Incukalns UGS, which also serves as a pledge of security all year round;

- An environment-friendly source of energy characterised by a low level of $\mathrm{CO} 2$ emissions and an efficient fuel with a high calorific value.

Weaknesses:

- Too few interconnections with other EU member states;

- The insufficient capacity of the Latvia-Lithuania interconnection.

Opportunities:

- Diversification of the natural gas supply paths, building new transmission system connections, and construction of a competitive LNG terminal;

- Supply of natural gas from Klaipeda LNG terminal;

- Setting up a Baltic natural gas trade platform/centre, with the participation of Latvia;

- If the natural gas consumption in the region increases in the long-term development of other potential natural gas storage sites, it allows for storage of natural gas for the markets of other EU countries;

- Increasing the natural gas storage potential at Incukalns UGS using the non-domestic storage potential;

- Development of the production of biogas, gas produced from wood biomass and EtO gas; introduction of these gases into the natural gas distribution system;

- Ample possibilities of using natural gas both in industrial equipment and in heat supply equipment, especially combined heat and power generation equipment with high energy efficiency, simultaneously generating heat and electric power;

- Using natural gas in the transport sector if gas-filling infrastructure is ensured.

Threats:

- The possible increase in the natural gas price on the global market;

- Diminished natural gas consumption may increase the costs of using the gas infrastructure to the gas users;

- Supply interruptions during the period when gas is pumped into Incukalns UGS; 
- Insufficient gas supply in the period of high consumption (in the winter season) in case of accidents in the Baltic natural gas systems;

- Control of strategically important gas supply and storage infrastructure;

- As the natural gas consumption increases, Latvia's energy independence weakens.

Challenges:

- Lack of interconnections with other EU countries, which hampers the development of the underground gas storage potential in Latvia;

- Insufficiently diversified natural gas supply sources and paths, leading to a strong dependence on one supplying country. As the natural gas supply paths develop in Estonia and Finland, reverse gas flow - from Estonia to Latvia there will be no reverse gas flow;

- Insufficient capacity of the Latvia-Lithuania interconnection for meeting the Latvian gas demand in the case when the gas demand is extremely high and the supply of gas from Incukalns UGS is interrupted;

- For regional security needs, it would be important to enlarge Incukalns UGS [3], [8], [9].

\section{CONCLUSIONS}

The main critical points of the system have been determined within the framework of the research. First of all, these include the border-area GMSs, with a total capacity of 23 million $\mathrm{m}^{3} /$ day, for example GMS Korneti (in the territory of Latvia) - 17 million $\mathrm{m}^{3} /$ day and GMS Kiemenai (in the territory of Lithuania). The present capacity of GMS Kiemenai is 6.24 million $\mathrm{m}^{3} /$ day, still after the reconstruction of the station; it will be possible to increase it to 10 million billion $\mathrm{m}^{3} /$ day. Border-area GMS Karksi (in the territory of Estonia), which has a gas-metering capacity of 7 million billion $\mathrm{m}^{3} /$ day, operates only in the direction towards Estonia and is mainly used in winter, during the heating season. In order to ensure the possibility to transport gas from Estonia to Latvia, this GMS needs to be equipped with a reverse metering unit.

In the territory of Latvia, there are 44 GRS. As a result of the study, three GRS have been chosen as critical points (Riga 1, Riga 3 and Ziemeli) since they serve the largest natural gas consumer in Latvia - the city of Riga with adjoining gasified areas. According to the 2015 report data, the total consumption in Riga makes up $73 \%$ of the country's total consumption. These GRS also supply gas to energy facilities: Riga CHP-1 and 2 as well as facilities of JSC Rigas Siltums.

Incukalns UGS has also been ranked among the most critical point of the system. This is due to the fact that in the winter season, as the demand of natural gas for heat generation needs increases, the capacity of the pipelines is not sufficient to meet the natural gas demand of the whole Baltic region. Therefore, in winter, during the heating season, the gas stored in Incukalns UGS is used, which is supplied from the UGS to the consumers of Latvia and, partly, Estonia. In the summer season, when gas is pumped into Incukalns UGS, in an average daily amount of 16 million billion $\mathrm{m}^{3}$ /day, reaching 17 million billion $\mathrm{m}^{3} /$ day on some days.

Considering the permissible working pressure of the gas pipeline Valday- 
Pskov-Riga (44...47 bar), such an amount corresponds to the maximum capacity of the pipeline, serving an average gas demand of $2 \ldots 2.2$ million $\mathrm{m}^{3} /$ day in Latvia as well as pumping of gas into Incukalns UGS. At the same time, Incukalns UGS needs to be enlarged and modernized.

\section{REFERENCES}

1. ENTSOG data. (n.d.). Retrieved 9 March 2017, from https://www.entsog.eu/

2. The Ministry of Economics of the Republic of Latvia. (n.d.). Energetikas tirgus un infrastruktūra. Retrieved 9 March 2017, from https://www.em.gov.lv/lv/nozares_politika/ energijas_tirgus_un_infrastruktura/LR Ekonomikas ministrija.

3. The Ministry of Economics of the Republic of Latvia. (2011). Latvijas Energettikas ilgtermiņa stratēgija 2030 - konkurētspējīga energètika sabiedrībai. Riga: LR Ekonomikas ministrija. Retrieved 28 February 2017, from http://www.latea.lv/userfiles/ news/14122011_Energetikas_strategija_2030.pdf

4. Dabasgāzes imports un patēriņš. Retrieved 27 February 2017, from http://www.csb.gov. lv/statistikas-temas/metodologija/dabasgazes-imports-un-paterins - 36922.html

5. JSC Latvijas Gaze. (2016). Internal information. Retrieved 26 February 2017, from http://www.lg.lv/index.php?id=209\&lang=eng

6. Bode, I. (2014). Sadales gāzesvadu sistēmu tehniskā stāvokḷa novērtēšanas metodologija. Promocijas darba kopsavilkums. Riga: RTU.

7. Niedrīte, I. (2017). Assessment of Natural Gas Supply System Security. PhD Thesis. Riga: RTU.

8. Jansons, L., Zeltins, N., \& Savickis, J. (2016). The Latvian UGS potential and alternative use of underground geological structures. In E-Proceedings of 23th World Energy Congress 2016 Istanbul - Research Papers, 9-13 October 2016, Lütfi Kırdar Congress Center, ISTANBUL. ISBN: 978-605-89548-9-2.

9. Niedrite, I., Kreslins, A., Davis, A., \& Zeltins, N. (2013). Security of gas supply risk assessment alternatives. Proceedings of 22nd World Energy Congress, Daegu, Korea, 17 October, 2013, No. 820.

10. CSB (n.d.). Retrieved 9 March 2017, from http://www.csb.gov.lv/

11. Ivanova, P., Sauhats, A., \& Linkevičs, O. (2016). Towards optimization of combined cycle power plants' start-ups and shut-down. 57th International Scientific Conference on Power and Electrical Engineering of Riga Technical University (RTUCON), Latvija, Riga.

12. Ivanova, P., Sauhats, A., Linkevičs, O., \& Balodis, M. (2016). Combined heat and power plants towards efficient and flexible operation. 2016 IEEE 16th International Conference on Environmental and Electrical Engineering (EEEIC), 6-8 June, 2016, Florence.

13. Moshkin, I., \& Sauhats, A. (2016). Solving district heating problems by using cooperative game theory methods. Proceedings of 16th International Conference on Environment and Electrical Engineering, EEEIC 2016, 6-8 June, 2016, Florence.

14. Soboḷevskis, A., \& Zicmane, I. (2016). Assessing the impact of registering of weak points calculating the power system operating modes. 57th International Scientific Conference on Power and Electrical Engineering of Riga Technical University (RTUCON), 12-13 October 2017.

15. AST data. (n.d.). Retrieved 9 March 2017, from http://www.ast.lv/

16. Rigas siltumapgādes attīstības koncepcija 2006.-2016.gadam. (2006). Retrieved 9 March 2017, from http://www.rea.riga.lv/files/Rigas\%20Siltumapgades\%20Attistibas\%20Koncepcija\%202006.-2016.\%20gadam.pdf 
17. JSC Rigas Siltums data. (2015). Retrieved 9 March 2017, from http://www.rs.lv/sites/ default/files/page_file/rs_gada_parskats_2015.pdf

18. Zemite, L., Gorobecs, M., Smats, A., Jasevics, A., \& Levchenkovs, A. (2017). Genetic algorithm for optimization of power switch allocation in distribution network. Proceedings of the 17th IEEE International Conference on Environment and Electrical Engineering and the 1st IEEE Industrial and Commercial Power Systems Europe, EEEIC / I and CPS Europe 2017.

19. Zemite, L., Gerhards, J., Gorobetz, M., \& Levchenkov, A. (2016). Optimization of distribution system reliability. In EEEIC 2016 - International Conference on Environment and Electrical Engineering, 6 - 8 June 2016, Florence.

20. Zemite, L., Gerhards, J., Gorobetz, M., \& Levchenkov, A. (2015). Optimization of distribution systems reliability with the stochastic behavior. In the 56th International Scientific Conference on Power and Electrical Engineering of Riga Technical University, RTUCON 2015, 14 October, 2015.

21. Zemite, L., \& Gerhards, J. (2014). Reliability evaluation of distribution systems. In 9th International Conference on Electrical and Control Technologies (ECT-2014), 8-9 May 2014, Kaunas, Lithuania.

22. Republic of Latvia Cabinet Regulation No. 496. (2010). Procedures for the Identification of Critical Infrastructures, Including European Critical Infrastructures and Planning and Implementation of Security Measures. Retrieved 9 March 2017, fromhttps://likumi. lv/doc.php?id=212031

23. ISO 31000:2009. Risk Management - Principles and Guidelines.

24. ISO/IEC 31010:2009. Risk Management - Risk Assessment Techniques.

\title{
LATVIJAS GĀZES - ELEKTROENERĞIJAS TĪKLS: GĀZES SISTĒMAS DATU ANÁLİZE
}

\author{
L. Zemīte, A. Kutjuns, I. Bode, M. Kunickis, N. Zeltiňš
}

Kopsavilkums

AS “Conexus Baltic Grid” ir vienotais dabasgāzes pārvades un glabāšanas operators Latvijā. Tas nodrošina Inčukalna pazemes gāzes krātuves (PGK), gāzesvadu caurulvadu sistēmā ar kopējo garumu 1191 km gāzes skaitītāju stacijas Korneti darbību. Latvijas dabasgāzes pārvades infrastruktūra ir daļa no Baltijas valstu dabasgāzes pārvades sistēmas. Inčukalna PGK ir viens no svarīgākajiem dabasgāzes infrastruktūras elementiem. Tas spēj uzglabāt līdz 2,32 miljardiem m³ aktīvās gāzes un l̦auj samazināt pieprasījuma svārstības Baltijas valstīs. Ziemas periodā patērētāji Latvijā saņem dabasgāzi no Inčukalna PGK. No tās dabasgāze tiek piegādāta arī patērētājiem Igaunijā un laiku pa laikam Lietuvā. Vasaras sezonā krātuvē vidēji diennaktī iesūknē 16 miljoni $\mathrm{m}^{3}$ gāzes N̦emot vērā piel̦aujamo darba spiedienu, šāds daudzums atbilst cauruḷvada maksimālajai jaudai, nodrošinot vidējo gāzes pieprasījumu Latvijā 2-2,2 miljonu $\mathrm{m}^{3}$ diennaktī. Šajā pētījumā tika noteikta dabasgāzes kritiskā infrastruktūra, gāzes pieprasījums un piegāde, kā arī tika veikta šîs sistēmas SVID analīze.

23.11.2017. 